\title{
The Protection of Hepatocyte Cells from the Effects of Oxidative Stress by Treatment with Vitamin E in Conjunction with DTT
}

\author{
Jen-Hsiang Tsai, ${ }^{1}$ Haw-Wen Chen, ${ }^{2}$ Yi-Wan Chen, ${ }^{3}$ Jer-Yuh Liu, ${ }^{4,5}$ and Chong-Kuei Lii ${ }^{2}$ \\ ${ }^{1}$ Department of Physical Therapy, School of Medical and Health Sciences, Fooyin University, Kaohsiung 83102, Taiwan \\ ${ }^{2}$ School of Nutrition and Institute of Nutrition, College of Health Care, China Medical University, Taichung 40402, Taiwan \\ ${ }^{3}$ School of Nutrition, College of Health Care and Management, Chung Shan Medical University, Taichung 40203, Taiwan \\ ${ }^{4}$ Graduate Institute of Cancer Biology, College of Medicine, China Medical University, Taichung 40402, Taiwan \\ ${ }^{5}$ Center for Molecular Medicine, College of Medicine, China Medical University, Taichung 40402, Taiwan
}

Correspondence should be addressed to Jer-Yuh Liu, jyl@mail.cmu.edu.tw and Chong-Kuei Lii, cklii@mail.cmu.edu.tw

Received 16 November 2009; Accepted 25 March 2010

Academic Editor: George E. Plopper

Copyright (C) 2010 Jen-Hsiang Tsai et al. This is an open access article distributed under the Creative Commons Attribution License, which permits unrestricted use, distribution, and reproduction in any medium, provided the original work is properly cited.

\begin{abstract}
We investigated the effect of vitamin $\mathrm{E}$ on membrane protein thiols under oxidative stress, which we induced by treating hepatocytes with tert-butyl hydroperoxide (TBH) for 60 mins. Those cells which we pretreated with vitamin E formed fewer blebs (22.3\% compared to $60.0 \%$ in nonvitamin E-treated cells) and maintained cytosolic calcium concentration and the number of membrane protein thiols instead of showing the usual symptoms in cells undergoing oxidative stress. Dithiothreitol (DTT) also commonly reduces bleb formation in hepatocytes affected by TBH. However, our experiments clearly demonstrate that DTT does not prevent the changes in cytosolic calcium and membrane protein thiols in the blebbing cells. Consequently, we decided to pretreat cells with both DTT and vitamin E and found that the influence of TBH was entirely prevented. These findings may provide us with a new aspect for investigating the mechanism of bleb formation under oxidative stress.
\end{abstract}

\section{Introduction}

Formation of blebs on the surface of hepatocytes is not only an early sign of toxic injury under ischemic conditions or oxidative stress but also has a significant association with apoptosis or necrosis [1]. This morphological abnormality has been attributed to a change in intracellular calcium homeostasis $[2,3]$. An increase in the concentration of intracellular calcium may induce a series of calcium-dependent reactions catalyzed by the calcium-dependent proteases, phospholipases, or endonucleases [4]. These enzymes may disrupt the integrity of the cytoskeleton and lead to bleb formation and growth. The course of plasma membrane blebbing on hepatocytes has been divided into three stages: formation, shedding and fusion, and finally rupture [5]. Injuries to hepatocytes in the first two stages are reversible whereas bleb rupture is irreversible and results in cell lysis [6].
In addition to its nutritional importance, vitamin $\mathrm{E}(\alpha$ tocopherol) is also a natural antioxidant which can prevent lipid peroxidation in cellular and subcellular membrane phospholipids under oxidative stress [7]. Lipid peroxidation may cause damage of the plasma membrane and an increase in the number of cytosolic-free calcium ions. This can result in the change in the verapamil and nifedipine-sensitive $\mathrm{Ca}^{2+}$ channels [8] or an increased possibility of arachidonic acidinduced toxicity of CYPE1-expressing cells [9]. This increase in cytosolic $\mathrm{Ca}^{2+}$ concentration can be prevented by vitamin $\mathrm{E}$; moreover, we have also demonstrated that vitamin $\mathrm{E}$ may prevent bleb formation and the loss of protein thiols in tertbutyl hydroperoxide-(TBH-) treated hepatocytes [10, 11]. Since vitamin E only protects protein thiols which have been depleted due to interaction with endogenously generated lipid peroxidation products [12], it is possible that the attenuation of plasma membrane protein thiols may be related to the maintenance of intracellular calcium homeostasis. 
In order to determine the role of vitamin $\mathrm{E}$ in this mechanism, we employed confocal microscopy, high-pressure liquid chromatography (HPLC), and spectrophotometry to investigate the changes in the concentration of intracellular calcium ions and the number of plasma membrane protein thiols of rat hepatocytes under oxidative stress induced by TBH.

\section{Materials and Methods}

2.1. Isolation and Culture of Hepatocytes. All animal experiments were conducted with approval from Chung Shan Medical University Animal Care and Use Committee. Male Sprague-Dawely rats (8 weeks) were purchased from the National Animal Breeding and Research Center, Taipei, Taiwan. Hepatocytes were isolated from the liver of these animals by collagenase perfusion [10], and $>90 \%$ were found to be viable by the trypan blue exclusion test. The cells were then plated to collagen-precoated $30-\mathrm{mm}$ plastic tissue culture dishes (Falcon Labware, USA) with a total of $0.7 \times 10^{6}$ cells in L-15 culture medium $(\mathrm{pH}$ 7.6) containing $18 \mathrm{mM} \mathrm{N}$-2-hydroxyethylpiperazine- $\mathrm{N}^{\prime}-2$ ethanesulfonic acid (HEPES), 2.5\% fetal bovine serum, $5 \mathrm{mg} / \mathrm{L}$ each of insulin and transferrin, $5 \mu \mathrm{g} / \mathrm{L}$ sodium selenite, $1 \mathrm{~g} / \mathrm{L}$ galactose, $1 \mu \mathrm{mol} / \mathrm{L}$ dexamethasone, $100,000 \mathrm{IU} / \mathrm{L}$ penicillin, and $100 \mathrm{mg} / \mathrm{L}$ streptomycin. After culturing in a $37^{\circ} \mathrm{C}$ humidified incubator in ambient air for 4 hours, unattached and dead cells were removed from the culture. The cells were then cultured in the L- 15 culture medium with $0.2 \%$ bovine serum albumin without fetal bovine serum at $37^{\circ} \mathrm{C}$ for 4 hours; cells were incubated at $37^{\circ} \mathrm{C}$ without treatment or treated with $100 \mu \mathrm{M}$ vitamin $\mathrm{E}$ for 20 hours. Cultures with vitamin E treatment were then treated with $5 \mathrm{mM}$ dithiothreitol (DTT) for $15 \mathrm{~min}$ or without this treatment. Those without vitamin $\mathrm{E}$ treatment were treated with $5 \mathrm{mM}$ DTT and/or $15 \mathrm{mM}$ ethylene glycol tetraacetic acid (EGTA) for $15 \mathrm{~min}$ or without any treatment. These cultures were treated with indicated concentrations of $\mathrm{TBH}$, and changes in the cells were detected.

2.2. Confocal Microscopy. Alternations in intracellular calcium were determined by confocal microscopy with a calcium-sensitive fluorescent dye (fluo 3-AM) and video microscopic imaging using the method of Burnier et al. [13] with modifications. Fluo 3-AM $(5 \mu \mathrm{M})$ was added to culture medium, and the hepatocytes were incubated at $37^{\circ} \mathrm{C}$ for $30 \mathrm{~min}$ in the dark. The pluronic acid $(2 \mu \mathrm{L} / \mathrm{mL})$ was added to fluo 3-AM for dispersing the dye. After removing the culture medium, the cells were washed with L-15 culture medium without bovine serum albumin and then cultured with $1 \mathrm{~mL}$ of this medium in a $30-\mathrm{mm}$ culture dish.

After labeling with fluo 3-AM, the culture dish was placed into a thermostatic stage maintained at $37^{\circ} \mathrm{C}$. Hepatocytes with various treatments or without treatment were scanned under a confocal microscope (LSM 410 invert, Zeiss, Germany). Confocal microscopy was performed according to the procedures as previously described [13].
2.3. Cell Morphology Examination. Tissue culture dishes were placed on a heated microscope stage $\left(37^{\circ} \mathrm{C}\right)$. Following the addition of TBH, cell membrane bleb formation was monitored under a phase-contrast inverted microscope (Nikon, Tokyo, Japan) equipped with a CCD camera monitor. The percentage of hepatocytes-bearing blebs was determined on pictures that were taken at $15,30,45$, and 60 min, respectively. At least 150 cells were counted in each analysis. The percentage of cells-bearing blebs was used to express the extent of membrane blebbing in each group.

2.4. High-Pressure Liquid Chromatography. These cells were allowed to stand for $30 \mathrm{~min}$ to dissolve glutathione (GSH) into perchloric acid. To the acid solvent containing GSH $(400 \mu \mathrm{L}), 40 \mu \mathrm{L}$ iodoacetic acid $(120 \mathrm{mg} / \mathrm{mL})$ and potassium bicarbonate $\left(\mathrm{KHCO}_{3}\right)$ were added and placed in the dark for 15 min before adding $440 \mu \mathrm{L} 3 \%$ 2, 4-dinitrofluoro benzene in ethanol. The mixture was then vigorously shaken and stored at $4^{\circ} \mathrm{C}$ for 8 hours. After centrifuged at $6,000 \times \mathrm{g}$ for $5 \mathrm{~min}$, the supernatant was filtered through a $0.45-\mu \mathrm{m}$ filter. Concentrations of GSH were determined by HPLC using the method as previously described [14].

2.5. Spectrophotometry. To determine lipid peroxidation, hepatocytes were washed twice with cold phosphate-buffered saline (PBS, pH 7.4) after removal of the culture medium. The cells were extracted with $200 \mu \mathrm{L}$ of $50 \mathrm{mM}$ potassium phosphate buffer ( $\mathrm{pH}$ 7.4). Lipid peroxidation was determined as thiobarbituric acid reactive substances (TBARS) [15]. The fluorescence of the samples was detected at an excitation wavelength of $515 \mathrm{~nm}$ and an emission wavelength of $555 \mathrm{~nm}$ in a F4500 fluorescence spectrophotometer (Hitachi, Japan) and 1, 1, 3, 3-tetramethoxypropane was used as a TBARS standard.

For the determination of membrane protein thiols, the hepatocytes were washed twice with PBS, and $600 \mu \mathrm{L}$ of $20 \mathrm{mM}$ potassium phosphate buffer ( $\mathrm{pH}$ 7.4) was added, after removing the culture medium. The cells were then scraped and centrifuged at $800 \times \mathrm{g}$ for $10 \mathrm{~min}$. The supernatant was centrifuged again at $105000 \times \mathrm{g}$ to obtain the cytosolic fractions (supernatant) and the membrane fractions (pellet). The membrane fractions were then mixed thoroughly with the same buffer $(800 \mu \mathrm{L})$ containing $5 \%$ SDS. The total membrane protein thiols were measured after the incubation with 5,5' -dithio-bis-nitrobenzoic acid as previously described [16], and the total protein concentrations were determined by the method as previously described [17]. To express the cell viability, the lactate dehydrogenase (LDH) leakage was analyzed according to the method as previously described [18].

2.6. Statistical Analysis. Data were expressed as mean \pm standard deviation. Significant differences among the groups were analyzed by one-way analysis of variance. Duncan's multiple tests were used to determine the difference among groups, and Student's $t$-test was used in case of the two group comparison. $P<.05$ was considered to have statistical significance. 


\section{Results}

3.1. Initiation of Hepatocyte Blebbing by TBH and Changes in the Intracellular Calcium. Under the confocal microscope, the locations of blebs observed under the transmission mode corresponded to their intensities (Figures 1(a), 1(c), $1(\mathrm{e}), 1(\mathrm{~g})$, and 1(i)). The fluorescence intensity from the hepatocytes treated with $2.0 \mathrm{mM}$ TBH increased with time (Figures 1(b), 1(d), 1(f), 1(h), and 1(j)), such as cell a, b, c, $\mathrm{d}$, and e of Figure 1(b) whose concentration of intracellular calcium rapidly increased from $12 \mathrm{~min}$ and reached the maximum at $18 \mathrm{~min}$ (Figure 2). A significant increase in fluorescence intensity and a bleb in a hepatocyte were observed at $18 \mathrm{~min}$ after TBH treatment, as arrow indicated (Figures 1(e) and 1(f)). These changes became more severe at $30 \mathrm{~min}$, as arrow indicated (Figures $1(\mathrm{~g})$ and $1(\mathrm{~h})$ ). The fluorescence intensity disappeared at $60 \mathrm{~min}$ because of bleb rupture (Figures 1(i) and 1(j)).

3.2. Effects of Vitamin $E$ on the Intracellular Calcium in TBH-Treated Hepatocytes. In hepatocytes treated with 1.0 or $2.0 \mathrm{mM} \mathrm{TBH}$ for $60 \mathrm{~min}$ under a phase-contrast inverted microscope, $18 \% \pm 4.2 \%(n=3)$ or $60.6 \% \pm 1.1 \%$ $(n=4)$, respectively, formed blebs on the cell membrane. These phenomenons were similar to the observation of bleb formation from confocal microscope. Significantly lower percentage of $22.3 \% \pm 4.2 \%(n=4)$ in $2.0 \mathrm{mM} \mathrm{TBH}$-treated hepatocytes was obtained by the pretreatment with vitamin $\mathrm{E}(P<.05)$. Moreover, pretreatment with EGTA in $2.0 \mathrm{mM}$ TBH-treated hepatocytes also yielded a significantly lower of $27.4 \pm 5.8(n=4)$. However, no significant differences were found between the pretreatment with vitamin E and EGTA $(P>.05)$.

Although the fluorescence response in $1.0 \mathrm{mM} \mathrm{TBH}$ treated hepatocytes was not observed (data not shown), the positive response was detected at $12 \mathrm{~min}$ after treatment with $2.0 \mathrm{mM} \mathrm{TBH}$ (control) and increased to 2 folds at $18 \mathrm{~min}$ and gradually decreased from $40 \mathrm{~min}$. In $2.0 \mathrm{mM}$ TBH-treated hepatocytes pretreated with vitamin $\mathrm{E}$, the response was in a steady level and significantly lower than control in the middle period. Whereas, pretreated with EGTA in $2.0 \mathrm{mM}$ $\mathrm{TBH}$-treated hepatocytes, the concentration of intracellular calcium was gradually decreased from $15 \mathrm{~min}$, and to zero at 30 min (Figure 3(a)).

3.3. Effects of Vitamin E and DTT on the Intracellular Calcium in TBH-Treated Hepatocytes. In addition to vitamin E, DTT is also an important member of the antioxidative agent. Pretreatment with DTT significantly decreased the percentage of blebbing from $62.2 \% \pm 1.2 \%$ in the hepatocytes only treated with $2 \mathrm{mM}$ TBH for $60 \mathrm{~min}$ to $25.0 \% \pm 2.2 \%$ $(P<.05)$. However, after adding vitamin $\mathrm{E}$ with DTT to the $\mathrm{TBH}$-treated cells, the blebbing percentage was significantly reduced to zero.

The concentration of intracellular calcium response from the $2.0 \mathrm{mM}$ TBH-treated cells with pretreatment of DTT increased with time in the blebbing cells but no significant difference was found in the prior period (Figure 3(b)).
3.4. Effects of Vitamin E and DTT on Total Glutathione (GSH), LDH Leakage, and Lipid Peroxidation in TBHTreated Hepatocytes. Intracellular total GSH concentration significantly decreased after treating the hepatocytes with 1.0 or $2.0 \mathrm{mM}$ TBH for $60 \mathrm{~min}$, although the GSH concentration in $2.0 \mathrm{mM} \mathrm{TBH}$-treated cells was significantly lower than that of the $1.0 \mathrm{mM}$ TBH-treated ones. Pretreatment with vitamin E or DTT maintained GSH in $2.0 \mathrm{mM}$ TBH-treated hepatocytes; the levels of GSH were significantly lower than those of the untreated group. However, there was no significant difference in the GSH level between the vitamin E plus DTT-treated group and the untreated group (Table 1).

The levels of $\mathrm{LDH}$ leakage in hepatocytes treated with 1.0 or $2.0 \mathrm{mM}$ TBH, EGTA and $2.0 \mathrm{mM} \mathrm{TBH}$, or DTT and $2.0 \mathrm{mM}$ TBH were significantly higher than the untreated group. However, there was no significant difference in the leakage between the untreated group and $2.0 \mathrm{mM}$ TBHtreated cells with pretreatment of vitamin E or vitamin E plus DTT (Table 1).

Lipid peroxidation was measured by TBARS production in hepatocytes. TBARS production was significantly higher in the cells treated with 1.0 or $2.0 \mathrm{mM} \mathrm{TBH}$, DTT or EGTA with $2.0 \mathrm{mM} \mathrm{TBH}$ than the untreated group. However, there was no significant difference in the production between $2.0 \mathrm{mM}$ TBH-treated cells with the untreated group and pretreatment of vitamin E or vitamin E plus DTT (Table 1).

3.5. Effects of Vitamin E and DTT on the Loss of Membrane Protein Thiols Induced by TBH. In both membrane and cytosol, the levels of membrane protein thiols in hepatocytes treated with 1.0 or $2.0 \mathrm{mM} \mathrm{TBH}$ or EGTA and $2.0 \mathrm{mM}$ $\mathrm{TBH}$ for $60 \mathrm{~min}$ were significantly lower than the untreated group. In the presence of vitamin E, there was no significant difference in the level of protein thiols of the membrane fraction, whereas this level remained significantly lower than the untreated group in the cytosolic fraction. In the pretreatment with DTT in $2.0 \mathrm{mM}$ TBH-treated hepatocytes, although the levels of protein thiols of the membrane fraction were significantly lower than these of the control, there was no significant difference in the cytosolic fraction. However, no significant difference was found in the level of protein thiols of both the membrane and cytosolic fractions in the vitamin E plus DTT pretreated cells (Table 2).

In the cells without the supplement of vitamin E, treatment of $2.0 \mathrm{mM}$ TBH caused a rapid loss of the membrane protein thiols and $37 \%$ of the thiols were lost within $15 \mathrm{~min}$. The percentage of loss then became less severe after $15 \mathrm{~min}$, and a total loss of $41 \%$ was observed at $60 \mathrm{~min}$ after TBH treatment. In the presence of vitamin $\mathrm{E}$, the percentage of loss was also more severe in the first $15 \mathrm{~min}$. However, the total loss of thiols was only $15 \%$ at $60 \mathrm{~min}$.

\section{Discussion}

The formation of blebs in TBH-treated hepatocytes has been attributed to the elevation of intracellular calcium concentration $[19,20]$. Using confocal microscopy, we visually demonstrated the important role of intracellular 


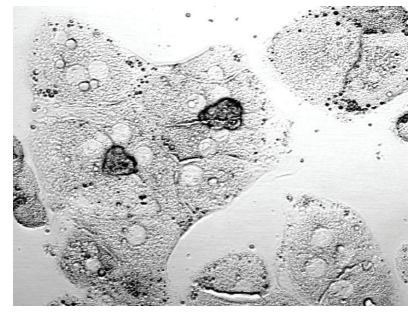

(a)

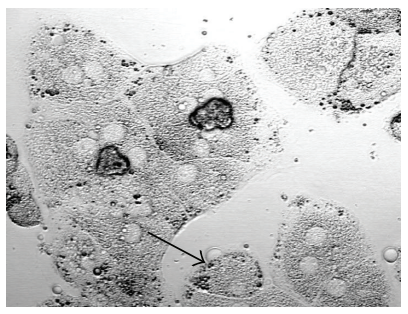

(c)

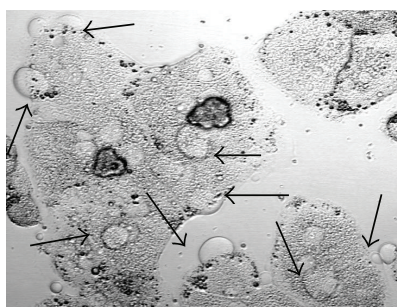

(e)

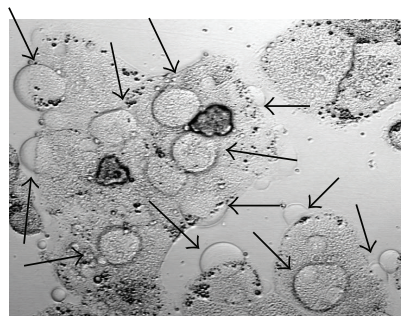

(g)

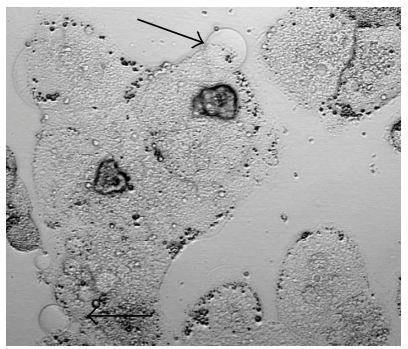

(i)

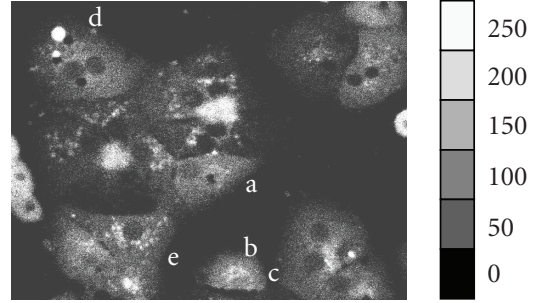

(b)

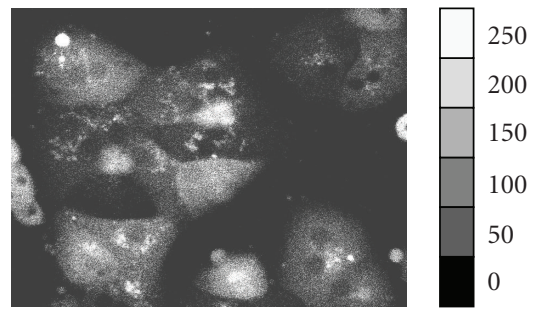

(d)

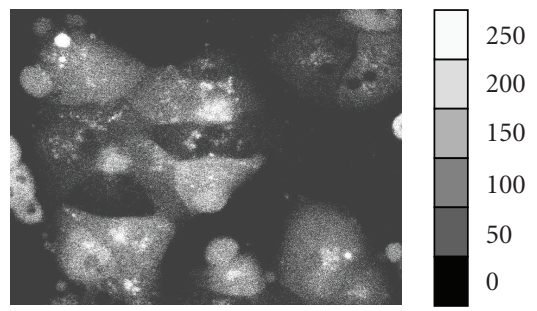

(f)

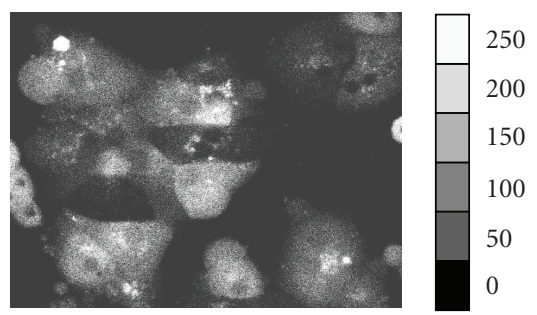

(h)

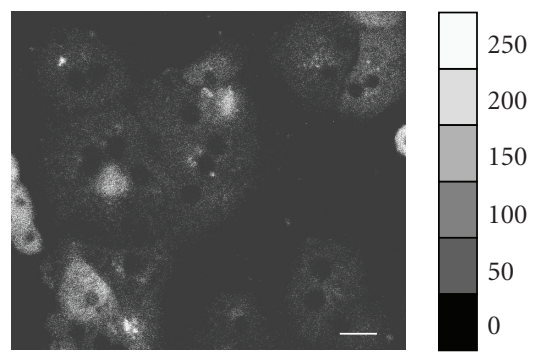

(j)

FIgURE 1: Changes in the fluorescence intensity of intracellular calcium in TBH-treated hepatocytes. Using confocal microscopy, the changes of cell morphology were also photographed before (a), 12 (c), 18 (e), 30 (g), and $60 \mathrm{~min}$ (i) after $2.0 \mathrm{mM}$ TBH treatment. At the same time, the changes of fluorescence intensity of intracellular calcium were photographed before (b), 12 (d), 18 (f), 30 (h) and $60 \mathrm{~min}(\mathrm{j})$ after $2.0 \mathrm{mM}$ $\mathrm{TBH}$ treatment. Pseudodensity scale indicates fluorescence intensity in arbitrary units. Arrows indicate the cells with bleb. Bar, $20 \mu \mathrm{m}$. 
TABLE 1: Effect of vitamin E and DTT on total GSH content, LDH leakage, and TBARS production in rat hepatocytes with TBH treatment.

\begin{tabular}{lccc}
\hline Treatment & Total GSH $(\mathrm{nmol} / \mathrm{mg}$ protein) & LDH leakage $(\%)$ & TBARS $(\mathrm{nmol} / \mathrm{mg}$ protein $)$ \\
\hline Untreated & $47.7 \pm 4.5^{\mathrm{a}}$ & $1.2 \pm 0.6^{\mathrm{a}}$ & $0.66 \pm 0.09^{\mathrm{ab}}$ \\
TBH $(1.0 \mathrm{mM})$ & $19.5 \pm 8.5^{\mathrm{bc}}$ & $43.8 \pm 7.6^{\mathrm{b}}$ & $1.31 \pm 0.41^{\mathrm{ac}}$ \\
TBH $(2.0 \mathrm{mM})$ & $4.1 \pm 1.2^{\mathrm{d}}$ & $76.2 \pm 13.8^{\mathrm{c}}$ & $3.90 \pm 0.31^{\mathrm{d}}$ \\
Vitamin E $(100 \mu \mathrm{M})+\mathrm{TBH}(2.0 \mathrm{mM})$ & $9.1 \pm 0.2^{\mathrm{b}}$ & $7.6 \pm 2.2^{\mathrm{a}}$ & $0.41 \pm 0.11^{\mathrm{b}}$ \\
EGTA $(15 \mathrm{mM})+\mathrm{TBH}(2.0 \mathrm{mM})$ & $2.1 \pm 0.1^{\mathrm{d}}$ & $62.8 \pm 2.2^{\mathrm{c}}$ & $2.73 \pm 0.51^{\mathrm{e}}$ \\
DTT $(5 \mathrm{mM})+\mathrm{TBH}(2.0 \mathrm{mM})$ & $29.7 \pm 3.5^{\mathrm{ce}}$ & $26.6 \pm 1.7^{\mathrm{e}}$ & $1.75 \pm 0.20^{\mathrm{c}}$ \\
Vitamin E $(100 \mu \mathrm{M})+$ DTT $(5 \mathrm{mM})+\mathrm{TBH}(2.0 \mathrm{mM})$ & $36.9 \pm 4.2^{\mathrm{ae}}$ & $2.8 \pm 1.1^{\mathrm{a}}$ & $0.55 \pm 0.06^{\mathrm{b}}$ \\
\hline
\end{tabular}

Values are expressed as means $\pm \mathrm{SD}(n=3-4)$. Means in the same column not sharing the same superscripts differ significantly $(P<.05)$.

TABLE 2: Effect of vitamin E and DTT on the loss of membrane protein thiols in TBH-treated hepatocytes 60 min after treatment.

\begin{tabular}{|c|c|c|}
\hline \multirow{2}{*}{ Treatment } & \multicolumn{2}{|c|}{ Protein thiol level (\%) } \\
\hline & Membrane & Cytosol \\
\hline Untreated & $100^{\mathrm{a}}$ & $100^{\mathrm{a}}$ \\
\hline $\mathrm{TBH}(1.0 \mathrm{mM})$ & $78.7 \pm 4.7^{\mathrm{b}}$ & $83.6 \pm 6.9^{\mathrm{b}}$ \\
\hline $\mathrm{TBH}(2.0 \mathrm{mM})$ & $59.0 \pm 8.3^{\mathrm{c}}$ & $71.1 \pm 7.9^{c}$ \\
\hline Vitamin $\mathrm{E}(100 \mu \mathrm{M})+\mathrm{TBH}(2.0 \mathrm{mM})$ & $85.4 \pm 13.2^{\mathrm{a}}$ & $76.8 \pm 2.9^{c}$ \\
\hline EGTA $(15 \mathrm{mM})+\mathrm{TBH}(2.0 \mathrm{mM})$ & $76.1 \pm 3.2^{\mathrm{b}}$ & $83.6 \pm 2.1^{\mathrm{b}}$ \\
\hline $\mathrm{DTT}(5 \mathrm{mM})+\mathrm{TBH}(2.0 \mathrm{mM})$ & $75.7 \pm 3.1^{\mathrm{b}}$ & $96.4 \pm 5.5^{\mathrm{a}}$ \\
\hline Vitamin $\mathrm{E}(100 \mu \mathrm{M})+\mathrm{DTT}(5 \mathrm{mM})+\mathrm{TBH}(2.0 \mathrm{mM})$ & $114.2 \pm 8.8^{\mathrm{a}}$ & $92.2 \pm 10.0^{\mathrm{a}}$ \\
\hline
\end{tabular}

Values are expressed as mean $\pm \mathrm{SD}(n=3-4)$. Means in the same column not sharing the same superscripts differ significantly $(P<.05)$.

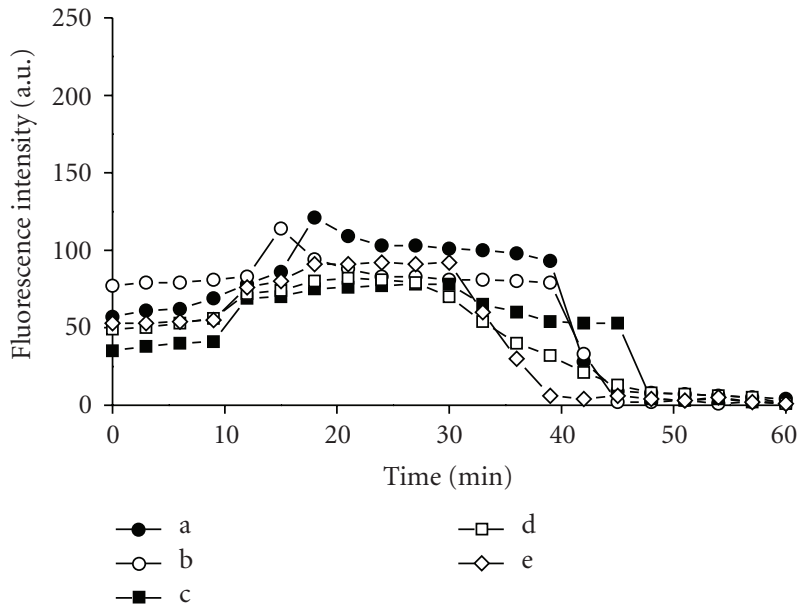

FIGURE 2: Kinetics of changes in the concentration of intracellular calcium in cell a, b, c, d, and e of Figure 1 before and after treated with $2.0 \mathrm{mM}$ TBH.

calcium in the formation of blebs on the cell membrane of hepatocytes treated with TBH. A significant increase in fluorescence intensity and multiple bleb formation in a single hepatocyte were observed and the intensity of fluorescence was proportional to the size of blebs. By pretreating hepatocytes with EGTA to remove the extracellular calcium, we found that no fluorescence intensity was observed and that the percentage of blebbing significantly decreased from $61 \%$ in the control group to $27 \%$. Moreover, treatment with EGTA after bleb formation also reduces the percentage of blebbing. These data confirmed that bleb formation is associated with the increase in concentration of intracellular calcium. However, since lipid peroxidation causes damage of the plasma membrane which results in an increase in the number of cytosolic free calcium ions [8], the prevention of blebbing may be due to the combination of EGTA with the intracellular iron which is required for lipid peroxidation [21]. In order to rule out this possibility, we analyzed the effect of EGTA on the lipid peroxidation caused by TBH and found that EGTA did not decrease lipid peroxidation under oxidative stress. Although EGTA does not affect lipid peroxidation under oxidative stress, treatment with this compound protects TBH-treated cells from death by preventing the increase in concentration of intracellular calcium [22, 23]. These findings confirm that the intracellular calcium increase caused by $\mathrm{TBH}$ is exclusively due to calcium influx from the extracellular site $[22,24]$ and indicate the importance of intracellular calcium in the formation of plasma membrane blebbing.

There is a positive correlation between lipid peroxidation in the membrane and the loss of membrane protein thiols [25]. Our previous study demonstrated that protection of cell morphology by vitamin $\mathrm{E}$ is associated with protein thiols $[10,11]$. Vitamin E prevents the death of cultured hepatocytes treated with TBH $[26,27]$. It has also been reported that calcium accumulation caused by lipid peroxidation is completely prevented by vitamin $\mathrm{E}$ [8]. In this study, we demonstrated that vitamin $\mathrm{E}$ not only blocks the elevation of intracellular calcium concentration but also prevents the loss of protein thiols in the membrane of $\mathrm{TBH}$-treated hepatocytes. These findings indicate that the integrity of cell membrane conserved by vitamin E may be important in the maintenance of intracellular calcium homeostasis. 


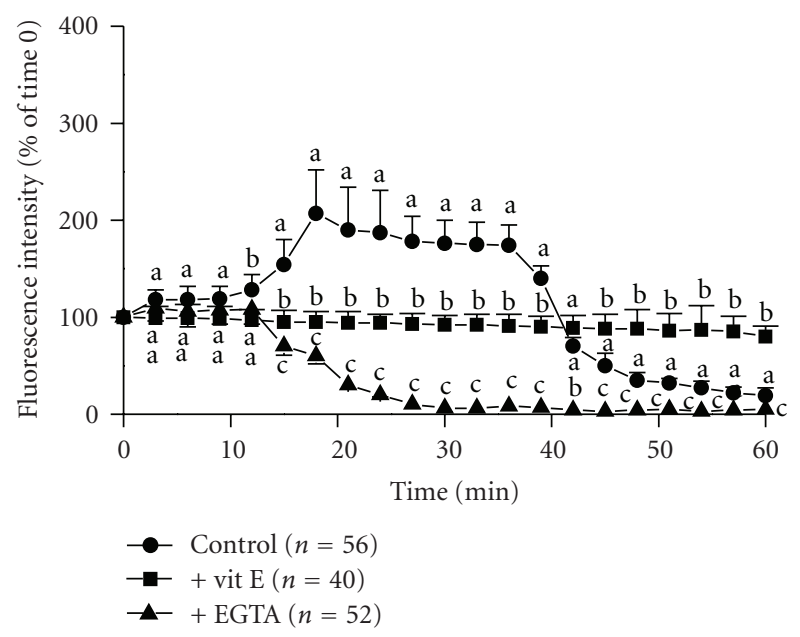

(a)

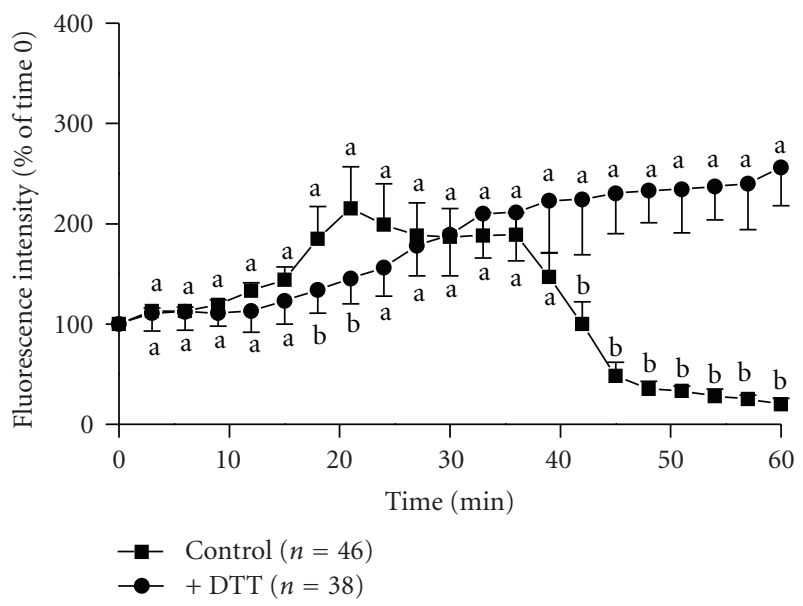

(b)

FIgure 3: The effect of vitamin E and DTT on the concentration of intracellular calcium in TBH-treated hepatocytes. (a) Changes in concentration of intracellular calcium were determined in the cells treated with $2.0 \mathrm{mM} \mathrm{TBH}$ (control), with $2.0 \mathrm{mM} \mathrm{TBH}$ by the pretreatment with $100 \mu \mathrm{M}$ vitamin E for $20 \mathrm{~h}$, or with $15 \mathrm{mM}$ EGTA for $15 \mathrm{~min}$. (b) Changes in concentration of intracellular calcium were determined in the cells treated with $2.0 \mathrm{mM} \mathrm{TBH}$ (control) or with $2.0 \mathrm{mM} \mathrm{TBH}$ by the pretreatment with $5.0 \mathrm{mM}$ DTT for $15 \mathrm{~min}$. The results were based on three separate experiments, and the values are expressed as mean \pm SD. Treatment means in the same time not sharing the same superscripts differ significantly $(P<.05)$.

Although there is an association between membrane blebbing and intracellular calcium concentration, blebbing may also be induced by other mechanisms, since blebs were found in $22 \%$ of the hepatocytes pretreated with vitamin $\mathrm{E}$, after $\mathrm{TBH}$ treatment. It has been reported that the alteration of cytosolic free calcium may not be required for bleb formation $[28,29]$. Moreover, $\mathrm{Hg}^{2+}$-treated hepatocytes also form blebs on the cell membrane, and the level of blebbing is independent of the concentrations of intracellular calcium [30]. In this study, we found that although DTT reduces the loss of cytosolic protein thiols and decreases bleb formation in $\mathrm{TBH}$-treated hepatocytes, it can not prevent an increase in the concentration of intracellular calcium in cells which do form blebs. However, pretreatment with both vitamin E and DTT entirely blocks bleb formation, maintains intracellular calcium homeostasis, and prevents total protein thiol loss, lipid peroxidation, and the consumption of GSH. This indicates that plasma membrane blebbing is relatively complex and may be due to many factors.

Although it has been reported that DTT is effective in preserving the homeostasis of intracellular calcium and the integrity of the cell membrane $[31,32]$, the controversial results may be due to different cell conditions, different time courses and varying treatment doses. Based on the observations in this study, vitamin E specifically prevents the loss of protein thiols in the plasma membrane, while DTT specifically prevents the loss of protein thiols in the intracellular site. Thus, these data indicate that vitamin $\mathrm{E}$ may preserve the integrity of the cell membrane by the protection of membrane protein thiols and hence maintain intracellular calcium homeostasis of hepatocytes under oxidative stress. These findings suggest that the different effects of vitamin $\mathrm{E}$ and DTT may provide us with a new aspect for investigating the mechanism of bleb formation under oxidative stress and for developing a new preventative strategy.

\section{Acknowledgment}

This work was supported by a Grant from the National Science Council (NSC 87-2314-B-040-002 and NSC 882314-B-040-001), Taiwan.

\section{References}

[1] H. A. Arab, F. Sasani, M. H. Rafiee, A. Fatemi, and A. Javaheri, "Histological and biochemical alterations in earlystage lobar ischemia-reperfusion in rat liver," World Journal of Gastroenterology, vol. 15, no. 16, pp. 1951-1957, 2009.

[2] S. A. Jewell, G. Bellomo, and H. Thor, "Bleb formation in hepatocytes during drug metabolism is caused by disturbances in thiol and calcium ion homeostasis," Science, vol. 217, no. 4566, pp. 1257-1259, 1982.

[3] D. J. McConkey and S. Orrenius, "The role of calcium in the regulation of apoptosis," Journal of Leukocyte Biology, vol. 59, no. 6, pp. 775-783, 1996.

[4] M. J. Berridge, M. D. Bootman, and P. Lipp, "Calcium-a life and death signal," Nature, vol. 395, no. 6703, pp. 645-648, 1998.

[5] B. Herman, A. L. Nieminen, G. J. Gores, and J. J. Lemasters, "Irreversible injury in anoxic hepatocytes precipitated by an abrupt increase in plasma membrane permeability," The FASEB Journal, vol. 2, no. 2, pp. 146-151, 1988.

[6] G. J. Gores, B. Herman, and J. J. Lemasters, "Plasma membrane bleb formation and rupture: a common feature of hepatocellular injury," Hepatology, vol. 11, no. 4, pp. 690-698, 1990.

[7] E. Niki, "Action of ascorbic acid as a scavenger of active and stable oxygen radicals," American Journal of Clinical Nutrition, vol. 54, no. 6, supplement, pp. 1119S-1124S, 1991.

[8] E. Albano, G. Bellomo, M. Parola, R. Carini, and M. U. Dianzani, "Stimulation of lipid peroxidation increases the intracellular calcium content of isolated hepatocytes," Biochimica et Biophysica, vol. 1091, no. 3, pp. 310-316, 1991. 
[9] A. A. Caro and A. I. Cederbaum, "Role of intracellular calcium and phospholipase A2 in arachidonic acid-induced toxicity in liver cells overexpressing CYP2E1," Archives of Biochemistry and Biophysics, vol. 457, no. 2, pp. 252-263, 2007.

[10] S.-T. Wang, J.-H. Kuo, R.-G. Chou, and C.-K. Lii, "Vitamin $\mathrm{E}$ protection of cell morphology and protein thiols in rat hepatocytes treated with tert-butyl hydroperoxide," Toxicology Letters, vol. 89, no. 2, pp. 91-98, 1996.

[11] H.-W. Chen, T. Chiang, C.-Y. Wang, and C.-K. Lii, "Inhibition of tert-butyl hydroperoxide-induced cell membrane bleb formation by $\alpha$-tocopherol and glutathione," Food and Chemical Toxicology, vol. 38, no. 12, pp. 1089-1096, 2000.

[12] P. Dogterom, G. J. Mulder, and J. F. Nagelkerke, "Lipid peroxidation-dependent and -independent protein thiol modifications in isolated rat hepatocytes: differential effects of vitamin E and disulfiram," Chemico-Biological Interactions, vol. 71, no. 2-3, pp. 291-306, 1989.

[13] M. Burnier, G. Centeno, E. Burki, and H. R. Brunner, "Confocal microscopy to analyze cytosolic and nuclear calcium in cultured vascular cells," American Journal of Physiology, vol. 266, no. 4 part 1, pp. C1118-C1127, 1994.

[14] D. J. Reed, J. R. Babson, and P. W. Beatty, "High-performance liquid chromatography analysis of nanomole levels of glutathione, glutathione disulfide, and related thiol and disulfides," Analytical Biochemistry, vol. 106, no. 1, pp. 55-62, 1980.

[15] C. G. Fraga, B. E. Leibovitz, and A. L. Tappel, "Lipid peroxidation measured as thiobarbituric acid-reactive substances in tissue slices. Characterization and comparison with homogenates and microsomes," Free Radical Biology and Medicine, vol. 4, no. 3, pp. 155-161, 1988.

[16] A. F. Boyne and G. L. Ellman, "A methodology for analysis of tissue sulfhydryl components," Analytical Biochemistry, vol. 46, no. 2, pp. 639-653, 1972.

[17] O. H. Lowry, N. J. Rosebrough, A. L. Farr, and R. J. Randall, "Protein measurement with the Folin phenol reagent," The Journal of Biological Chemistry, vol. 193, no. 1, pp. 265-275, 1951.

[18] P. Moldeus, J. Hogberg, and S. Orrenius, "Isolation and use of liver cells," Methods in Enzymology, vol. 52, pp. 60-71, 1978.

[19] H. Miyoshi, K. Umeshita, M. Sakon, et al., "Calpain activation in plasma membrane bleb formation during tert-butyl hydroperoxide-induced rat hepatocyte injury," Gastroenterology, vol. 110, no. 6, pp. 1897-1904, 1996.

[20] L. M. Pérez, P. Milkiewicz, J. Ahmed-Choudhury, et al., "Oxidative stress induces actin-cytoskeletal and tightjunctional alterations in hepatocytes by a $\mathrm{Ca}^{2+}$-dependent, PKC-mediated mechanism: protective effect of PKA," Free Radical Biology and Medicine, vol. 40, no. 11, pp. 2005-2017, 2006.

[21] G. Minotti and S. D. Aust, "The role of iron in oxygen radical mediated lipid peroxidation," Chemico-Biological Interactions, vol. 71, no. 1, pp. 1-19, 1989.

[22] I. Sakaida, A. P. Thomas, and J. L. Farber, "Increases in cytosolic calcium ion concentration can be dissociated from the killing of cultured hepatocytes by tert-butyl hydroperoxide," Journal of Biological Chemistry, vol. 266, no. 2, pp. 717-722, 1991.

[23] J. Heo, G. H. Kim, K. S. Lee, et al., "Effect of $\mathrm{Ca}^{2+}$ channel blockers, external $\mathrm{Ca}^{2+}$ and phospholipase A2 inhibitors on tbutyl hydroperoxide-induced lipid peroxidation and toxicity in rat liver slices," The Korean Journal of Internal Medicine, vol. 12, no. 2, pp. 193-200, 1997.
[24] J.-A. Kim, Y. S. Kang, Y. O. Kim, S. H. Lee, and Y. S. Lee, "Role of $\mathrm{Ca}^{2+}$ influx in the tert-butyl hydroperoxideinduced apoptosis of HepG2 human hepatoblastoma cells," Experimental and Molecular Medicine, vol. 30, no. 3, pp. 137$144,1998$.

[25] A. Pompella, A. Romani, A. Benedetti, and M. Comporti, "Loss of membrane protein thiols and lipid peroxidation in allyl alcohol hepatotoxicity," Biochemical Pharmacology, vol. 41, no. 8, pp. 1255-1259, 1991.

[26] P. A. Glascott Jr., E. Gilfor, and J. L. Farber, "Effects of vitamin $\mathrm{E}$ on the killing of cultured hepatocytes by tert-butyl hydroperoxide," Molecular Pharmacology, vol. 41, no. 6, pp. 1155-1162, 1992.

[27] J.-H. Kuo, H.-W. Chen, R.-G. Chou, and C.-K. Lii, "Vitamin $\mathrm{E}$ protection of cell morphology under oxidative stress is related to cytoskeletal proteins in rat hepatocytes," Archives of Toxicology, vol. 71, no. 4, pp. 231-237, 1997.

[28] J. J. Lemasters, J. DiGuiseppi, A.-L. Nieminen, and B. Herman, "Blebbing, free $\mathrm{Ca}^{2+}$ and mitochondrial membrane potential preceding cell death in hepatocytes," Nature, vol. 325, no. 6099, pp. 78-81, 1987.

[29] A.-L. Nieminen, G. J. Gores, B. E. Wray, Y. Tanaka, B. Herman, and J. J. Lemasters, "Calcium dependence of bleb formation and cell death in hepatocytes," Cell Calcium, vol. 9, no. 5-6, pp. 237-246, 1988.

[30] A.-L. Nieminen, G. J. Gores, T. L. Dawson, B. Herman, and J. J. Lemasters, "Toxic injury from mercuric chloride in rat hepatocytes," Journal of Biological Chemistry, vol. 265, no. 4, pp. 2399-2408, 1990.

[31] M. Kretzschmar and W. Klinger, "The hepatic glutathione system-Influences of xenobiotics," Experimental Pathology, vol. 38, no. 3, pp. 145-164, 1990.

[32] P. Nicotera, D. McConkey, S.-A. Svensson, G. Bellomo, and S. Orrenius, "Correlation between cytosolic $\mathrm{Ca}^{2+}$ concentration and cytotoxicity in hepatocytes exposed to oxidative stress," Toxicology, vol. 52, no. 1-2, pp. 55-63, 1988. 

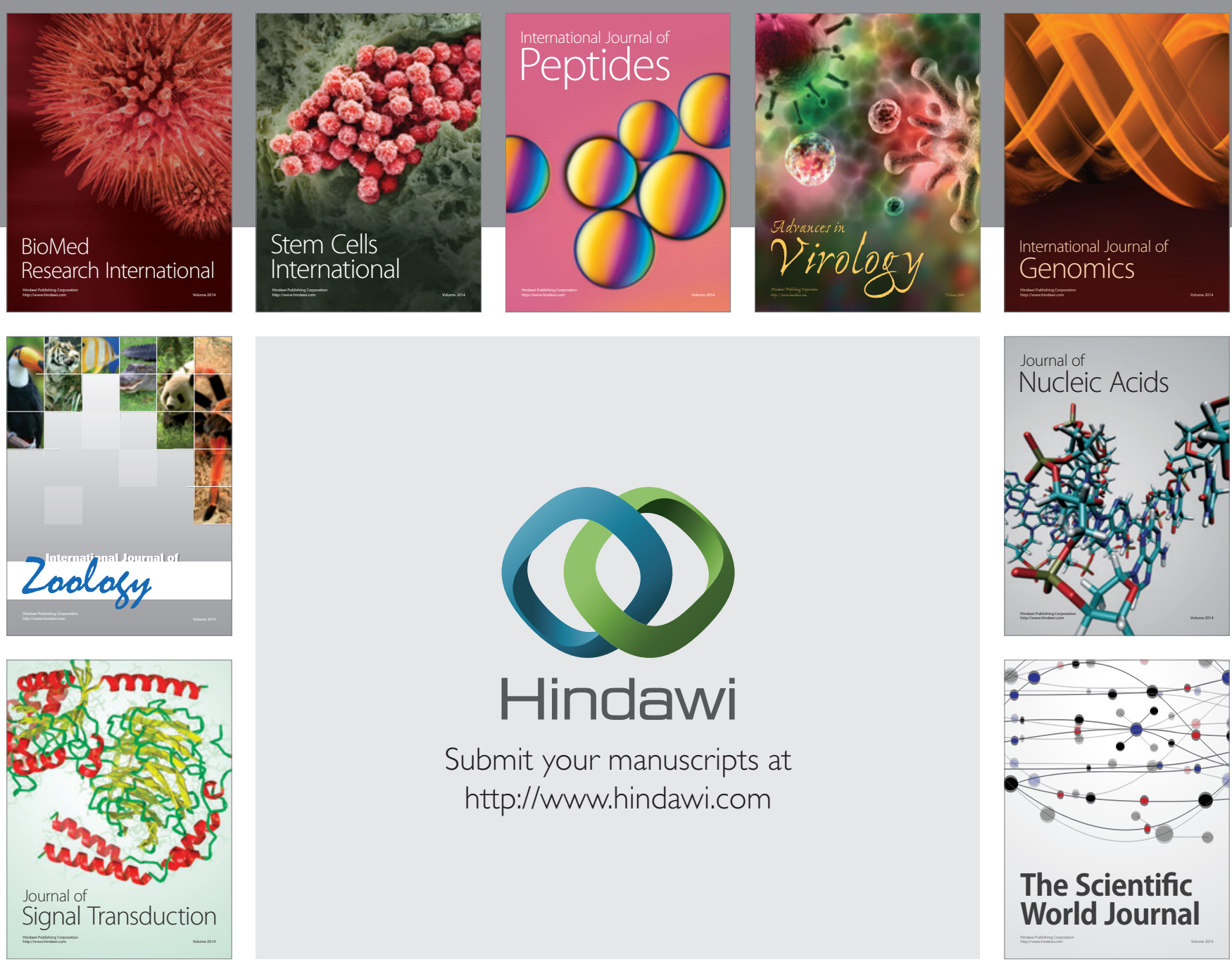

Submit your manuscripts at

http://www.hindawi.com
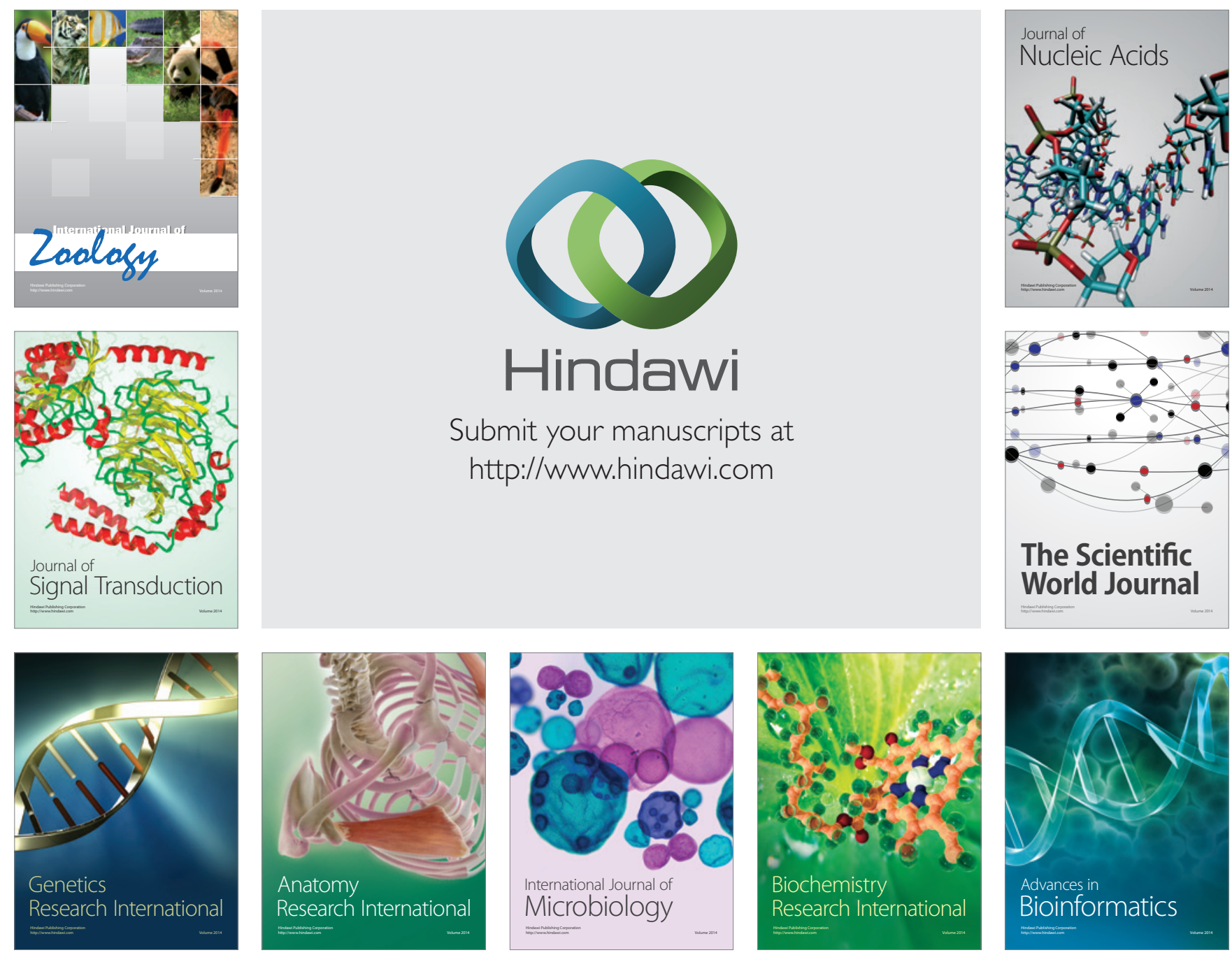

The Scientific World Journal
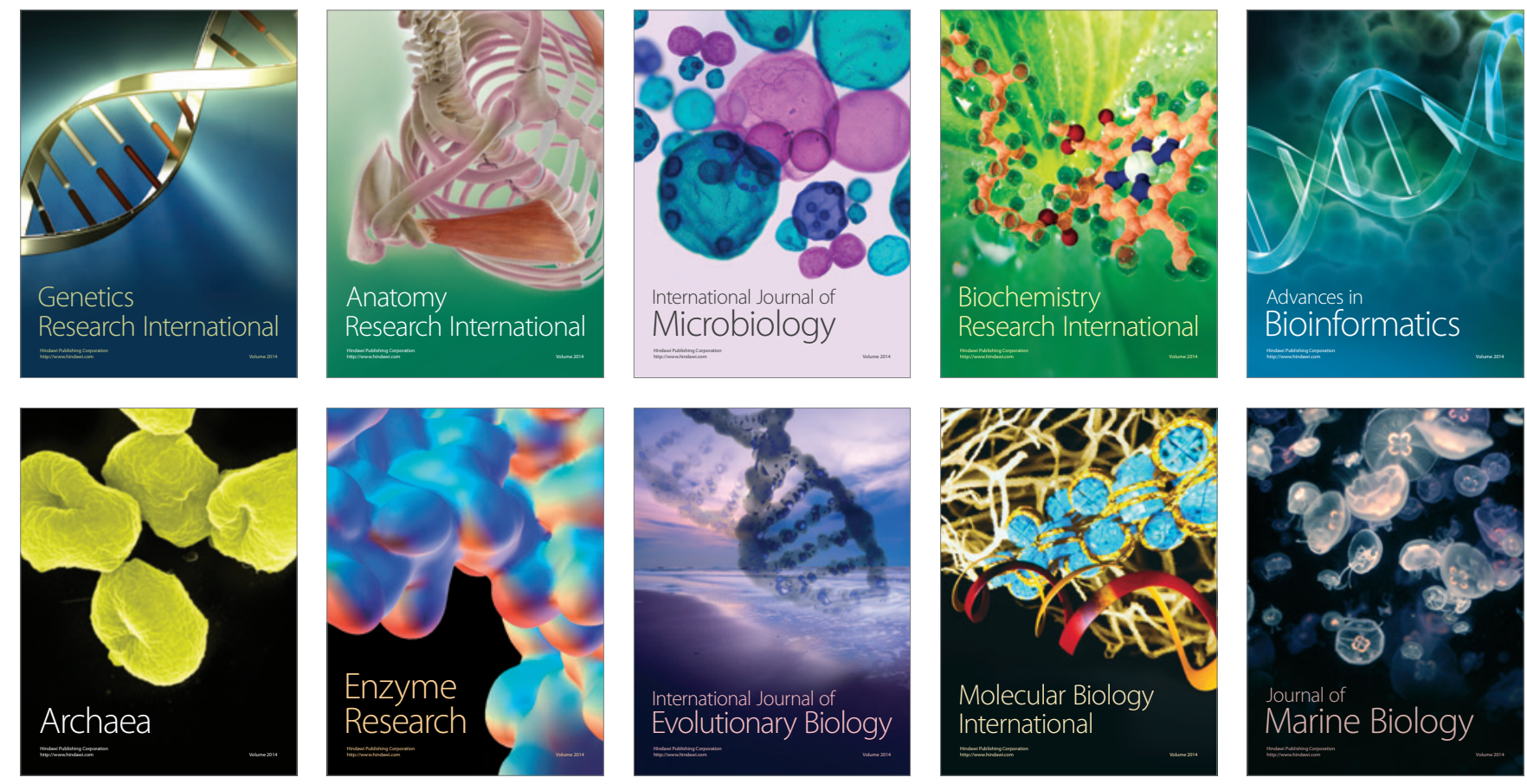